\title{
ECONOMICS

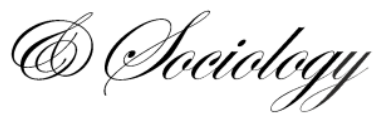

\section{THE IMPACT OF DIVISIA MONEY ON MONETARY MODEL OF EXCHANGE RATE IN INDONESIA}

\author{
Choi-Meng Leong, \\ UCSI University, \\ Kucbing, Malaysia, \\ E-mail:mandyleongcm@gmail.com
}

Chin-Hong Puah, Universiti Malaysia Sarawak, Kota Samaraban, Malaysia,

E-mail:chpuab@unimas.my

Venus Khim-Sen Liew, Universiti Malaysia Sarawak, Kota Samarahan, Malaysia, E-mail:ksliew@unimas.my

Received: January, 2018 1st Revision: March, 2018 Accepted: May, 2018

DOI: $10.14254 / 2071-$ 789X.2018/11-2/4

\footnotetext{
JEL Classification: E41, E52, C22.
}

Leong, C.-M., Puah, C.-H., Liew, V., K.-S. (2018). The Impact of Divisia Money on Monetary Model of Exchange Rate in Indonesia. Economics and Sociology, 11(2), 52-63. doi:10.14254/2071-789X.2018/11-2/4

\begin{abstract}
Stability of the exchange rate is critical for policy formulation in Indonesia and thus, has boosted the study of exchange rate behaviour. In this study, the monetary model of exchange rate has been utilised to determine the exchange rate for Indonesia. The model was improved by means of including the Divisia monetary aggregate as the money measure instead of conventional money supply. The ARDL approach, which was valid in spite of the variables' stationary properties, was used for the estimation. The findings indicated that monetary fundamentals are significant in explaining the exchange rate movements in Indonesia when Divisia money was incorporated into the monetary model of the exchange rate. As a result, monetary fundamentals can serve as the determinants of exchange rate in addition to non-monetary fundamentals in the case of Indonesia. High magnitude of the money supply differential and the real income differential coefficients also implied that monetary targeting can serve as a useful instrument for monetary policy in addition to inflation targeting. The research is based on the data ranging from 1984Q1 to 2017Q1.
\end{abstract}

Keywords: a monetary model of exchange rate, Divisia monetary aggregates, bounds testing, Indonesia.

\section{Introduction}

Exchange rate has become one of the critical transmission channels for external factors on monetary policy in emerging market economies as a result of financial integration (Filardo et al., 2011). Due to the dynamic context of both increased inflation and currency appreciation, the challenge for emerging market economies in formulating their monetary policies is to compromise between price stability and exchange rate stability. There has been an acceleration of the influence of external shocks and thus maintaining the stability of nominal exchange rates becomes vital for emerging market economies. In the short run, inflation can be affected by exchange rate movements and at the same time floating exchange rates serve as the shock absorber attaining macroeconomic stability. In the long run, exchange rate can affect external competitiveness. Fluctuations in exchange rates have the tendency to reduce revenues while at the same time increase the cost of exports and imports (Miciuła, 2014). Generally, exchange rates alter inflation, exports, imports as well as economic activity and thus remain to be an exceptionally critical macroeconomic variables in emerging and 
transition economies (Bunescu, 2014). Therefore, it is significant to examine the determinants of exchange rate movements to prevent momentous exchange rate deviations from the fundamentals that can affect macroeconomic performance.

A model that links exchange rate and macroeconomic fundamentals is the monetary model of exchange rate. This model emerged as a prominent exchange rate model after the breakdown of the Bretton Woods System in 1973. However, the empirical evidence surrounding the monetary exchange rate model are often inconsistent and sometimes contradictory (Simwaka, 2004). As this model is developed based on the money demand foundation, the model is very much dependent on the assumption of a stable money demand function (Bissoondeeal et al., 2009). Although there were many studies conducted to estimate monetary exchange rate model, there is lack of studies taking into account the financial liberalisation effect. Financial liberalisation has led to instability of money demand function (Goldfeld and Sichel, 1990; Caruso, 2006). Lane (1991) claimed that unstable money demand contributed to the failure of the monetary exchange rate model. As Indonesia also experiences financial liberalisation such as interest rate liberalisation, bank deregulation and competition, financial market development, management and supervision and capital account openness (Dekle and Pradhan, 1997), it is significant to incorporate the effect of financial liberalisation in the estimation of money demand function.

Monetary aggregate adjustment was used by Binner et al. (2004) to capture the effect of financial liberalisation in money demand function. The conventional money supply, also named as the simple sum monetary aggregate, has been used for the estimation of the money demand function. The use of the simple sum monetary aggregate in the estimation of macroeconomic models has been frequently criticised as it assumes that all monetary assets have equal weight although different returns are generated by numerous monetary assets. This is due to interest-bearing assets that have emerged during the period of financial liberalisation and also that the role of money has been enhanced to serve for savings purposes. As a result, the velocity of money has changed, leading to instability of the money demand function. The conventional money supply has failed to retain a stable link with macroeconomic fundamentals during the era of financial innovation.

Barnett (1980) proposed the use of Divisia monetary aggregates to gauge the total monetary services provided by monetary assets that possess different returns. This monetary aggregate is constructed based on the weighted sum method of monetary aggregation, in which financial assets with recurring transactions are given higher weights while financial assets used for savings purposes are assigned lower weights. The link between money supply and macroeconomics variables is strengthened when Divisia money is used. For instance, the Divisia monetary aggregate provided more information about inflation using the P-star model in the context of Indonesia (Tang et al., 2015). Furthermore, monetary policy shocks possessed greater and persistent effects on output and price when Divisia money was employed (Belongia and Ireland, 2016). In terms of money demand studies, Puah and Hiew (2010), Leong et al. (2010), Hendrickson (2013) and Sianturi et al. (2017) retrieved stable money demand functions using Divisia monetary aggregates. In addition, the estimation of balanced growth theory and classical money demand were also supported when Divisia money was employed (Serletis and Gogas, 2014). Therefore, the use of the Divisia monetary aggregate is proposed in the estimation of the monetary model of the exchange rate for Indonesia, one of the emerging market economies.

In Indonesia, a diffusion of policy liberalisation transpired during the period of 1984 to 1990 (Miranti, 2010). From 1985 to 1997, Indonesia registered a period of economic success and has undergone massive policy reforms (Stern, 2003). In 1997, the contagion effect of the Asian Financial Crisis spread to Indonesia. The devaluation of the Thai baht in 1997 led the Asian region to an economic crisis and altered the macroeconomic policies of 
Asian countries (Berg, 1999). Indonesia adopted the managed floating exchange rate system prior to the Asian Financial Crisis in 1997. The exchange rate was stable and thus the role of the exchange rate channel as the transmission mechanism of monetary policy was minimal.

However, exchange rate movements became important during the post-crisis period as Indonesia changed the exchange rate regime to a floating exchange rate system. The objective of Bank Indonesia was to achieve the stability of the Indonesian currency (Rupiah) and the central bank was given complete sovereignty to formulate the policy (Goeltom, 2008). The inflation expectations were affected by the price inaction and exchange rate, in which the movements of the exchange rate were determined by most of the non-monetary factors such as terms of trade, the relative price of non-traded to traded goods, net foreign assets, risk premium and interest rate differential (Goeltom, 2008). Thus, there was room to reconsider the use of monetary fundamentals in determining the exchange rate. If monetary fundamentals are found significant, these variables can serve as the alternative fundamentals to predict the exchange rate movements in Indonesia with the intention of forming the inflation expectations. Besides that, monetary targeting was the policy target for Indonesia during the stabilisation period of the International Monetary Fund program where base money served as the operational target to attain the ultimate target (Goeltom, 2008). Indonesia has only implemented the full inflation targeting framework since the year 2005. However, the implementation of inflation targeting to achieve reduced inflation has not always met the expected outcomes in Indonesia (Inoue et al., 2012). Therefore, the use of monetary targeting can be reconsidered in the case of Indonesia. The evaluation needs to be based on the effectiveness of monetary targeting, which entails the functioning of monetary fundamentals in the sense that the growth rates of money are strongly associated with the monetary policy's tools (Cabos et al., 2001). By keeping the stability of the Indonesian currency in focus, monetary fundamentals are proposed to determine the exchange rate in Indonesia via the estimation of the monetary exchange rate model.

The empirical evidence for the monetary model of the exchange rate usually covers the investigation of the long-run equilibrium of the monetary models. Lee et al. (2009) who investigated the long-run validity of monetary fundamentals and the exchange rate found that the monetary models that incorporated Divisia money were more stable. A recent study by Barnett et al. (2016) found that the Divisia measurement of money contributed markedly in elucidating the response of the exchange rate corresponding to interest rate shocks. With the empirical success of Divisia money, this paper seeks to use the Divisia monetary aggregate as the proxy for the money supply in the monetary model of the exchange rate. This aims to verify the effectiveness of the monetary fundamentals to derive stable money demand for policy formulation in Indonesia.

\section{Methodology and data description}

In order to examine the monetary model of the exchange rate for Indonesia, the autoregressive-distributed lag (ARDL) approach to cointegration was employed. Although Johansen-Juselius (1990) is the common method used in the literature to identify the long-run relationship between the variables, the method is not suitable for a country that undergoes financial liberalisation. Under financial liberalisation, standard cointegration test violates the assumption of time-invariant in the cointegration vector and thus the ADRL approach that offers asymptotic critical value bounds for Wald test is appropriate (James, 2005). Majid (2008) put forward the use of the bounds test for ample reasons. Firstly, the ARDL approach is valid in spite of the variables' stationary properties and at the same time permits for the inferences on long-run estimates. Secondly, the ARDL model also works well in general-tospecific modelling by taking in an adequate number of lags to maintain the data generating 
process. Lastly, the bounds test is capable of offering robust results in the analysis of a smallsize sample. The ARDL model also can be applied to a large sample size study as critical values have been generated by Pesaran and Pesaran (1997) and Pesaran et al. (2001) based on 500 and 1000 observations, in which the replications are 20,000 and 40,000, respectively (Duasa, 2007). Prior studies have utilised the ARDL approach in the investigation of the monetary model of the exchange rate with a different purpose for the estimation (Long and Samreth, 2008; Evans, 2013; Haghighat and Shojaei, 2014; Güneş and Karul, 2016). However, there is a lack of study that has used the ARDL model in the estimates of the monetary model of the exchange rate that incorporates the Divisia monetary aggregate as a proxy of the money supply. Consequently, this study utilises the ARDL model for the estimation of the monetary model of the exchange rate, in which the model is described as follows.

As the monetary model of the exchange rate is founded on the money demand function, the money demand functions for domestic and foreign countries can be defined as:

and

$$
m_{t}-p_{t}=a+b y_{t}-c r_{t}
$$

$$
m_{t}^{*}-p_{t}^{*}=a+b^{*} y_{t}^{*}-c^{*} r_{t}^{*}
$$

where $m_{t}, p_{t}, y_{t}$ and $r_{t}$ designate the money supply, aggregate price level, real income and nominal interest rate, respectively. The asterisks represent the corresponding foreign variables. $a$ is the constant parameter. $b$ is the coefficient for the real income and $c$ is the coefficient for the nominal interest in domestic country while $b^{*}$ is the coefficient for the foreign real income and $c^{*}$ is the coefficient for the foreign nominal interest rate. The income elasticity and interest rate semi-elasticity of money demand are assumed to be identical for domestic and foreign countries (Neely and Sarno, 2002). By assuming that $b=b^{*}$ and $c=c^{*}$, subtracting Equation (2) from Equation (1) as well as substituting $p_{t}-p_{t}^{*}$ with the nominal exchange rate $\left(e_{t}\right)$, the monetary exchange rate model is specified as:

$$
e_{t}=\beta_{1}\left(m_{t}-m_{t}^{*}\right)-\beta_{2}\left(y_{t}-y_{t}^{*}\right)+\beta_{3}\left(r_{t}-r_{t}^{*}\right)+\mu_{t}
$$

where $\left(m_{t}-m_{t}^{*}\right)$ denotes the money supply differential, $\left(y_{t}-y_{t}^{*}\right)$ designates the real income differential and $\left(r_{t}-r_{t}^{*}\right)$ is the relative short-term interest rate. The asset approach includes forward looking criteria for the exchange rate, which means that today's price will be closely connected to the next period's price. In the monetary model of the exchange rate, the uncovered interest rate parity will hold continuously as bonds are assumed to be perfect substitutes, where:

$$
E_{t}\left(\Delta e_{t+k}\right)=\left(r_{t}-r_{t}^{*}\right)
$$

As a result, Equation (3) will be simplified to:

$$
e_{t}=\beta_{0}+\beta_{1}\left(m_{t}-m_{t}^{*}\right)-\beta_{2}\left(y_{t}-y_{t}^{*}\right)+\mu_{t} .
$$

The simple monetary model (Frankel, 1979; Taylor and Peel, 2000) indicated that the nominal exchange rate is determined by the money supply differential and the real income differential. The money supply differential is positively related to the nominal exchange rate. When the local money supply is found to increase relative to a foreign counterpart, currency depreciation will take place in the local country. Conversely, the impact of the real income differential on the exchange rate will be indirect via money demand. The rise in home income 
relative to a foreign counterpart generates excess demand for money. In order to attain money market equilibrium, reduction in expenditure and prices are required in the course of action to increase real money balances. Subsequently, an appreciation of the currency will take place through purchasing power parity (PPP). Therefore, the expected signs of the coefficients are $\beta_{1}=1$ and $\beta_{2}<0$. The coefficient of 1 for the money supply differential signifies money neutrality (Cao and Ong, 1995).

Equation (5) is then transformed into the restricted ARDL model in order to approximate the cointegration relationship among the variables, which can be specified as:

$$
\begin{aligned}
\Delta e_{t}=\gamma_{0} & +\sum_{i=1}^{p} \gamma_{1 i} \Delta e_{t-i}+\sum_{i=0}^{q_{1}} \gamma_{2 i} \Delta d m_{t-i}+\sum_{i=0}^{q_{2}} \gamma_{3 i} \Delta d y_{t-i} \\
& +\theta_{1} e_{t-1}+\theta_{2} d m_{t-1}+\theta_{3} d y_{t-1}+\mu_{t}
\end{aligned}
$$

where $\Delta$ represents the first difference operator. The drift component and the white noise residual are denoted as $\gamma_{0}$ and $\mu_{t}$, respectively. $d m$ and $d y$ are the money supply differential and the real income differential. The asymptotic distribution of the F-statistic developed by Pesaran et al. (2001) was used to approximate the null hypothesis. If the computed F-statistic value is found to be larger than the upper critical value, then the null hypothesis of no cointegration is rejected. Conversely, the null hypothesis of cointegration cannot be rejected when the computed F-statistic value is relatively smaller compared to the lower critical value, which supports no cointegration among the tested variables. An inconclusive inference needs to be made if the computed F-statistic value falls between the upper and lower bounds.

In order to determine the short-run dynamics of the variables, the reduced form of the monetary exchange rate model in the ARDL error-correction model framework is depicted as follows:

$$
\Delta e_{t}=\gamma_{0}+\sum_{i=1}^{p} \quad \gamma_{1 i} \Delta e_{t-i}+\sum_{i=0}^{q_{1}} \quad \gamma_{2 i} \Delta d m_{t-i}+\sum_{i=0}^{q_{2}} \quad \gamma_{3 i} \Delta d y_{t-i}+\varphi E C_{t-1}+\mu_{t}
$$

where $E C_{t-1}$ stands for the lagged error correction term acquired from the estimated cointegration model that was expressed in Equation (6). If $E C_{t-1}$ is found to be statistically significant, then there is a long-run causality that runs from the explanatory variables to the dependent variable. The adjustment of the short-run deviation towards long-run equilibrium or the speed of adjustment is measured by the parameter of $\varphi$.

In term of the analysis, both the long-run and short-run periods are included since the ability of monetary fundamentals to perform in the dynamic economic environment is critical in both the short-run and long-run to retain currency stability under a floating exchange rate system. Quarterly data ranging from 1984Q1 to 2017Q1 was used to estimate the monetary model of exchange rate in order to capture the performance of the monetary fundamentals in the long-run and short-run. The year 1984 marked the beginning of policy liberalisation that boosted economic development in Indonesia. The data was obtained from various issues of the International Financial Statistics Yearbook as well as data compiled by the Euromoney Institutional Investor Company (CEIC database). In addition, the data of Divisia M2 money for the US was obtained from the Federal Reserve Bank of St. Louis. The end of period rupiah per US dollar (Rp/USD) was used to express the nominal exchange rate while the income in both Indonesia and US was proxied by the gross domestic product. All of the variables are expressed in natural logarithms. 


\section{Results and discussion}

Even though the testing of the unit root is not a pre-required condition of utilising the ARDL approach to cointegration (Akinlo, 2006; Duasa, 2007), it is important to verify the non-existence of variables in the second order of integration (Ahmed et al., 2013). As a result, the Phillips-Perron (PP) unit root test was employed to test the order of integration among the variables. The results of the PP unit root test are presented in Table 1.

Table 1. Phillips-Perron unit root test result

\begin{tabular}{lllll}
\hline \multirow{2}{*}{ Series } & \multicolumn{2}{c}{ Level } & \multicolumn{2}{c}{ First Difference } \\
\cline { 2 - 5 } & Intercept & Trend \& Intercept & Intercept & Trend \& Intercept \\
\hline$e$ & $-1.4208(4)$ & $-2.0471(4)$ & $-8.7596(4) * * *$ & $-8.5554(4)^{* * *}$ \\
\hline$m$ & $-2.0922(4)$ & $-0.0678(4)$ & $-14.0198(4) * * *$ & $-14.5072(4)^{* * *}$ \\
\hline$y$ & $-1.8478(4)$ & $-1.8558(4)$ & $-8.9352(4) * * *$ & $-8.9301(4)^{* * *}$ \\
\hline
\end{tabular}

Notes: Asterisks (***) denote significance at the $1 \%$ level. $e$ is the logarithm of the nominal rupiah/USD exchange rate, $m$ is the logarithm of the Divisia money supply differential and $y$ is the logarithm of the real income differential.

Source: own compilation.

Based on the Phillips-Perron unit root test results, all of the variables used for estimation were stationary at the first difference and thus indicated that none of the variables was integrated of order two. Consequently, the application of the bounds testing approach to cointegration is valid in this study. The variables in the model consist of the nominal exchange rate $(e)$ the Divisia money supply $(m)$ and the real income differential $(y)$. The Akaike Information Criterion (AIC) was used to select the optimal lag length for the model. Table 2 presents the results of the ARDL approach to cointegration.

Table 2. Results of the bounds test for cointegration

\begin{tabular}{|c|c|c|c|}
\hline Models & & \multicolumn{2}{|c|}{ F-statistic [Lag Order] } \\
\hline Model: $e, m$ and $y$ & & 2.2468[ & \\
\hline \multicolumn{4}{|c|}{ Critical values bounds of the F-statistic: unrestricted intercept and no trend } \\
\hline \multirow{2}{*}{ Significance level } & Pesaran Critical Values & Naray & Values \\
\hline & $I(0) \quad I(1)$ & $I(0)$ & $I(1)$ \\
\hline $90 \%$ level & 4.14 & 3.260 & 4.247 \\
\hline $95 \%$ level & 3.79 & 3.940 & 5.043 \\
\hline $99 \%$ level & 6.36 & 5.407 & 6.783 \\
\hline
\end{tabular}

Notes: Critical values were obtained from Pesaran et al. (2001), Table Case III: unrestricted intercept and no trend as well as Narayan (2005), Table Case III: unrestricted intercept and no trend.

Source: own compilation.

The computed F-statistic value for the model is 2.2468, which was less than the lower critical values of Pesaran et al. (2001) and Narayan (2005) at the 5 percent significance level. Consequently, there was no cointegration found between all of the included variables. In other words, the variables are not bounded together in the long run. Nevertheless, a more efficient approach to determine cointegration among the variables is the ARDL error correction model (Pahlavani et al., 2005). According to Weliwita and Ekanayake (1998), the estimates of the error correction model are essential since one of the causes of the severe misspecification problem, in a dynamic relationship, is the overlooking of the cointegration among the variables. The error correction model enables the determination of the long-run relationship 
among the variables with a different order of integration as well as the ability to generate results for both short-run and long-run dynamics concurrently. The existence of cointegration can be verified through the significance of error correction (EC) and the negative sign of the EC coefficient (Kremers et al., 1992). Therefore, the error correction model is also applied to reconfirm the existence of a long-run relationship among the variables. The results of the error correction model are presented in Table 3.

Table 3. Error-correction representation and diagnostic test results

\begin{tabular}{llc}
\hline \multicolumn{1}{c}{ Regressor } & Model: $e, m$ and $y(5,7,5)$ & \\
\hline Panel (i): Error-correction representation of the ARDL & -statistics \\
\hline Regressors & Coefficients & 2.2017 \\
\hline$\Delta$ Constant & $0.2992^{* *}$ & -1.1000 \\
\hline$\Delta e_{\mathrm{t}-1}$ & -0.0893 & -0.8681 \\
\hline$\Delta e_{\mathrm{t}-2}$ & -0.0655 & -3.5232 \\
\hline$\Delta e_{\mathrm{t}-3}$ & $-0.2525^{* * *}$ & 6.4610 \\
\hline$\Delta e_{\mathrm{t}-4}$ & $0.4939^{* * *}$ & 1.5970 \\
\hline$\Delta m$ & 0.0930 & -1.5502 \\
\hline$\Delta m_{\mathrm{t}-1}$ & -0.0903 & 1.1815 \\
\hline$\Delta m_{\mathrm{t}-2}$ & 0.0692 & 2.2453 \\
\hline$\Delta m_{\mathrm{t}-3}$ & $0.1335^{* *}$ & -1.0812 \\
\hline$\Delta m_{\mathrm{t}-4}$ & -0.0709 & -1.3254 \\
\hline$\Delta m_{\mathrm{t}-5}$ & -0.0634 & -3.3705 \\
\hline$\Delta m_{\mathrm{t}-6}$ & $-0.1563^{* * *}$ & -39.7027 \\
\hline$\Delta y$ & $-0.9461^{* * *}$ & -1.0524 \\
\hline$\Delta y_{\mathrm{t}-1}$ & -0.0830 & -0.4096 \\
\hline$\Delta y_{\mathrm{t}-2}$ & -0.0289 & -1.5294 \\
\hline$\Delta y_{\mathrm{t}-3}$ & -0.1055 & 6.8856 \\
\hline$\Delta y_{\mathrm{t}-4}$ & $0.4764^{* * *}$ & -2.2158 \\
\hline EC $\mathrm{t}-1$ & $-0.0638^{* *}$ \\
\hline Panel (ii): Diagnostic test for the ARDL estimation \\
\hline Serial Correlation & $6.4867[0.166]$ & \\
\hline Functional Form & $0.3639[0.546]$ & \\
\hline Normality & $3.4627[0.177]$ & \\
\hline Heteroskedasticity & $0.0055[0.941]$ & \\
\hline CUSUM & Stable & \\
\hline CUSUM of Squares & Stable & \\
\hline
\end{tabular}

Notes: The regressand is $e$. Asterisks (***), $(* *)$ and $(*)$ indicate that the null hypotheses are rejected at the $1 \%$, $5 \%$ and $10 \%$ significance levels, respectively. Serial Correlation denotes the Lagrange Multiplier (LM) test of residual serial correlation while Functional Form designates Ramsey's RESET test utilising the square of fitted values. The normality test is based on the skewness and kurtosis of residuals tests. The heteroskedasticity test is based on the regression of squared residuals on squared fitted values. The figures in (...) and [...] represent the lag length and probabilities, respectively.

Source: own compilation.

According to Hosein (2007), the short-run coefficients point toward the dynamic adjustment of every variable included in the estimates and thus it is not elucidated. A negative sign has been indicated by the coefficient of the lagged error correction term (EC) and it is statistically significant at the 5 percent level. The significance of EC indicates the tendency of exchange rate to revert to its equilibrium and thus the results concluded the existence of a long-run relationship between exchange rate and its fundamentals. Hwang (2001), Gharleghi and Mohd Nor (2012) also found that the error terms were significant and negative in their 
studies using different variants of the monetary model. The presence of long-run relationship among the variables implies that money supply differential and real income differential can be used to explain the movement of the exchange rate in Indonesia. Moreover, the economic development of US also needs to be taken into consideration in order to understand the movement of exchange rate in Indonesia. The speed of adjustment, which denotes the shortrun adjustment towards the long-run disequilibrium, is 6.38 percent, which is approximated to 15 quarters to adjust to the long-run disequilibrium of the Indonesian exchange rate. The robustness of the model was identified via diagnostic tests. The results in Table 3 indicate that the model passed a battery of diagnostic tests, which consisted of serial correlation, functional form, normality and heteroskedasticity tests. Besides that, this model was stable when CUSUM and CUSUM of square tests were applied. Therefore, a stable monetary exchange rate model has been derived for Indonesia. The achievement of the stability may due to the aggregation-theoretic monetary aggregates (Divisia) that able to stabilize the monetary equilibrium condition (Barnett and Chang, 2011).

With the presence of a cointegration relationship among the variables, the coefficient of the exchange rate is normalised to one in order to generate the long-run parameters. The ARDL estimation results are tabulated in Table 4. The coefficients sign of the Divisia money supply differential and real income differential are positive, which are consistent with the monetary model of exchange rate theory. Civcir (2004) and Adawo and Effiong (2014) found an identical sign of coefficient for the money supply differential and the real income differential in their studies. The positive value of the money supply differential coefficient indicates that when the money supply expands by one percent, the exchange rate depreciates by 0.46 percent. In order to achieve money market equilibrium, money supply expansions boost the price to increase. An increase in price leads to the depreciation of the exchange rate. In other words, Indonesian currency is sensitive to the money supply and thus central bank need to monitor the exchange rate to stabilize the currency. In order to defend Rupiah, tight monetary policy is recommended. Monetary fundamental is used to achieve inflation target in which the exchange rate pass-through induce monetary response on domestic economy via interest rate policy (Warjiyo, 2013).

In addition, the real income differential is negatively allied to the exchange rate. The size of the coefficient denotes that when the relative income increases by one percent, the exchange rate will appreciate by 0.68 percent. Thus, when the income of Indonesia is expected to grow faster than its US counterpart, the demand for domestic money increases. As a result, the expenditure and prices are expected to reduce in order to achieve money market equilibrium. A fall in Indonesian prices leads to an appreciation of the domestic currency via PPP. The finding supports the previous experience of Indonesia during Asian Financial Crisis, in which a rescue plan provided by International Monetary Fund was used to stabilize the exchange rate due to a 19.3\% reduction in the real income from 1997Q1 to 1998Q4 (Hsieh, 2009). Economic growth is critical to strengthen the exchange rate of Indonesia. Thus, real income differential can serve as a signal of the movement of exchange rate. In a nutshell, a parsimonious monetary exchange rate model for Indonesia can be derived using Divisia money.

Table 4. ARDL estimation results

\begin{tabular}{lc}
\hline Regressor & Model: $e, m$ and $y(5,7,5)$ \\
\hline \multirow{2}{*}{ Constant } & $4.6903^{* * *}$ \\
& {$[0.000]$} \\
\hline \multirow{2}{*}{$m$} & $0.4585^{* * *}$ \\
& {$[0.000]$} \\
\hline
\end{tabular}




\begin{tabular}{cc}
\hline$y$ & $-0.6753 * * *$ \\
& {$[0.000]$} \\
\hline
\end{tabular}

Notes: The regressand is $e$. Asterisks (***) indicate that null hypotheses are rejected at the 1\% significance level. The figures in (...) and [...] represent the optimal lag length, and probabilities, respectively.

Source: own compilation.

The joint significance for the total lags of every explanatory variable is tested by using the F-statistic. The results of the short-run estimates are demonstrated in Table 5. Only the real income differential Granger-cause the exchange rate, which implies that the impact of the money supply on the exchange rate is sluggish, which is consistent with the finding of the EC coefficient value. Money supply does not possess significant effect on the exchange rate since Indonesia implement floating exchange rate system (Marlissa, 2016), in which the exchange rate is also affected by the market responses. Consequently, only income differential can affect the exchange rate in the short run.

Table 5. Granger causality test results

\begin{tabular}{ll}
\hline Null Hypothesis & \\
\hline$m$ does not Granger cause $e$ & $0.2586[0.611]$ \\
\hline$y$ does not Granger cause $e$ & $17.3479[0.000]^{* * *}$ \\
\hline Notes: Asterisks $(* * *),(* *)$ and $(*)$ designate that the null hypotheses are rejected at the $1 \%, 5 \%$ and $10 \%$ \\
significance levels, respectively. The figures in $[\ldots]$ represent the probabilities. \\
urce $:$ own compilation.
\end{tabular}

\section{Conclusion and policy implications}

The relationship between the exchange rate, the money supply differential and the real income differential in Indonesia have been examined in this paper. The long-run relationship between the variables has been identified through the error correction model. In addition, the real income differential can Granger-cause the exchange rate in the short-run. The long-run parameters derived from the normalised equation in the model are used as the inference of a parsimonious model in Indonesia as all of the variables are significant and pass all of the diagnostic tests. The coefficients for both the money supply differential and the real income differential are significant and possess credible signs. Thus, the findings prove the significance of the monetary fundamentals to determine the exchange rate in Indonesia. Monetary policy is effective in monitoring the exchange rate of Indonesia as these economic variables can be used to determine the exchange rate movements that impinge on the real economy and prices. Besides that, the monetary fundamentals such as money supply differential and real income differential can also serve as the alternative variables to predict the change in the exchange rate on top of the initially employed non-monetary fundamentals such as terms of trade, the relative price of non-traded to traded goods, net foreign assets and risk premium in determining the exchange rate movements in Indonesia. Additional information can be provided by using monetary fundamentals as money supply differential can serve as the guideline for the implementation of loose or tight monetary policy while the change in real income differential provides signal to the change in the exchange rate.

In addition, the positive sign of the coefficient for the money supply differential also implies that an increase in the domestic money supply relative to the US will lead to a depreciation in the domestic currency. As a result, the implementation of a contractionary monetary policy can strengthen the Rupiah. On the other hand, the real income differential possesses a negative sign of coefficient which indicates that economic growth initiates an 
improvement in the value of the Indonesian currency. The high magnitude of the coefficients of the money supply differential and the real income differential implies that monetary targeting can serve as a useful instrument for monetary policy in addition to inflation targeting. In other words, the monetary aggregate is an intermediate target used to transmit the impact from the money supply to output and inflation.

Last but not least, the use of Divisia money as the money supply provides superior empirical evidence in the monetary model of the exchange rate. As a result, the Divisia monetary aggregate can be considered as an alternative money supply in addition to simple sum money in the monetary approach to exchange rate determination analysis for Indonesia.

\section{Acknowledgement}

Financial support from University of Malaysia Sarawak (UNIMAS) via Dana Principal Investigator research grant: 03(DPI21)985/2013(04) is gratefully acknowledged.

\section{References}

Adawo, M. A., Effiong, E. L. (2014). Monetary Exchange Rate Model as a Long-run Phenomenon: Evidence from Nigeria. Journal of Applied Economics and Business Research, 4(1), 52-63.

Ahmed, M. U., Muzib, M., Roy, A. (2013). Price-Wage Spiral in Bangladesh: Evidence from ARDL Bound Testing Approach. International Journal of Applied Economics, 10(2), 77-103.

Akinlo, A. E. (2006). The Stability of Money Demand in Nigeria: An Autoregressive Distributed Lag Approach. Journal of Policy Modeling, 28(4), 445-452.

Barnett, W. A. (1980). Economic Monetary Aggregates: An Application of Index Number and Aggregation Theory. Journal of Econometrics, 14, 11-48.

Barnett, W. A., Bhadury, S., Ghosh, T. (2016). An SVAR Approach to Evaluation of Monetary Policy in India: Solution to the Exchange Rate Puzzles in an Open Economy. Open Economies Review, 27(5), 871-893.

Barnett, W. A., Chang, H. K. (2011). Exchange Rate Determination from Monetary Fundamentals: An Aggregation Theoretic Approach. In: W. A. Barnett, \& M. Chauvet (eds.), Aggregation and Index Number Theory (pp. 151-166). Toh Tuck Link: World Scientific Publishing.

Belongia, M. T., Ireland, P. N. (2016). Money and Output: Friedman and Schwartz Revisited. Journal of Money, Credit and Banking, 48(6), 1223-1266.

Berg, A. (1999). The Asia Crisis causes policy responses and outcomes. IMF Working Paper No. WP/99/138.

Binner, J. M., Gazely, A. M., Chen, S.-H., Chie, B.-T. (2004). Financial Innovation and Divisia Money in Taiwan: Comparative Evidence from Neural and Vector ErrorCorrection Forecasting Models. Contemporary Economic Policy, 22, 213-224.

Bissoondeeal, R. K., Binner, J. M., Elger, T. (2009). Monetary Models of Exchange Rates and Sweep Programs. Applied Financial Economics, 19(14), 1117-1129.

Bunescu, L. (2014). The Impact of External Debt on Exchange Rate Variation in Romania. Economics and Sociology, 7(3), 104-115.

Cabos, K., Funke, M., Siegfried, N. A. (2001). Some Thoughts on Monetary Targeting vs. Inflation Targeting. German Economic Review, 2(3), 219-238.

Cao, Y., Ong, W. L. (1995). PPP and the Monetary Model of Exchange Rates Determination: The Case of Singapore. In: S. B. Chew, \& J. D. Kendall (eds.), Regional Issues in Economics, 1. Nanyang Business School: Nanyang Technological University. 
Caruso, M. (2006). Stock Market Fluctuations and Money Demand in Italy, 1913-2003. Economic Notes, 35(1), 1-47.

Civcir, I. (2004). The Long-run Validity of the Monetary Exchange Rate Model for a High Inflation Country and Misalignment: The Case of Turkey. Emerging Markets Finance and Trade, 40(4), 84-100.

Dekle, R., Pradhan, M. (1997). Financial liberalization and money demand in ASEAN countries: Implications for monetary policy. IMF Working Paper No. WP/97/36.

Duasa, J. (2007). Determinants of Malaysian Trade Balance: An ARDL Bound Testing Approach. Journal of Economic Cooperation, 28(3), 21-40.

Evans, O. (2013). The Monetary Model of Exchange Rate in Nigeria: An Autoregressive Distributed Lag (ARDL) Approach. MPRA Paper No.52457.

Filardo, A., Ma, G., Mihaljek, D. (2011). Exchange Rates and Monetary Policy Frameworks in EMEs. Bank of International Settlements (BIS) Papers No. 57, 37-63.

Frankel, J. A. (1979). On the mark: A theory of floating exchange rates based on real interest differential. American Economic Review, 69, 610-622.

Gharleghi, B., Mohd Nor, A. H. S. (2012). Is Monetary Variable a Determinant in the Ringgit-Dollar Exchange Rate Model? A Cointegration Approach. Sains Malaysiana, 41(9), 1163-1169.

Goeltom, M. S. (2008). The Transmission Mechanisms of Monetary Policy in Indonesia. Bank of International Settlements (BIS) Papers No. 35, 309-332.

Goldfeld, S. M., Sichel, D. E. (1990). The Demand for Money. In: B. M. Friedman \& F. H. Hahn (eds.), Handbook of Monetary Economics, 1 (pp. 300-355). Amsterdam: Elsevier Science Publishers.

Güneş, S. Karul, Ç. (2016). The Exchange Rate Overshooting in Turkey. Pamukkale Journal of Eurasian Socioeconomic Studies, 3(1), 27-35.

Haghighat, A., Shojaeu, T. (2014). Exchange Rate Overshooting in Iran. Academic Journal of Research in Economics \& Management, 2(3), 38-43.

Hendrickson, J. R. (2013). Redundancy or Mismeasurement: A Reappraisal of Money. Macroeconomic Dynamics, 18, 1437-1465.

Hosein, S. R. (2007). Demand for money in Iran: An ARDL approach. MPRA Paper No. 8224.

Hsieh, W.-J. (2009). Study of the behavior of the Indonesian Rupiah/US Dollar Exchange Rate and Policy Implications. International Journal of Applied Economics, 6(2), 41-50.

Hwang, J. K. (2001). Dynamic Forecasting of Monetary Exchange Rate Models: Evidence from Cointegration. International Advances in Economic Research, 7(1), 51-64.

Inoue, T., Toyoshima, Y., Hamori, S. (2012). Inflation Targeting in Korea, Indonesia, Thailand, and the Philippines: The Impact on Business Cycle Synchronization between Each Country and the World. Institute of Developing Economies Discussion Paper No. 328.

International Monetary Fund, International Financial Statistics, various issues. Washington, D.C.: IMF.

James, G. A. (2005). Money Demand and Financial Liberalization in Indonesia. Journal of Asian Economics, 16, 817-829.

Johansen, S., Juselius, K. (1990). Maximum Likelihood Estimation and Inference on Cointegration - With Applications to the Demand for Money. Oxford Bulletin of Economics and Statistical, 52(2), 169-210.

Kremers, J., Ericsson, N. Dolado, J. (1992). The Power of Cointegration Tests. Oxford Bulletin of Economics and Statistics, 54, 325-348.

Lane, T. D. (1991). Empirical Models of Exchange Rate Determination: Picking Up the Pieces. Economia Internazionale, 44, 210-226. 
Lee, C., Azali, M., Masih, A. M. M. (2009). Tests of the Different Variants of Monetary Model in a Developing Economy: Malaysian Experience in the Pre- and Post-crisis Periods. Applied Economics, 41, 1893-1902.

Leong, C. M., Puah, C. H., Shazali, A. M., Evan, L. P. H. (2010). Testing the Effectiveness of Monetary Policy in Malaysia Using Alternative Monetary Aggregation. Margin - The Journal of Applied Economic Research, 4(3), 321-338.

Long, D., Samreth, S. (2008). The Monetary Model of Exchange Rate: Evidence from the Philippines Using ARDL Approach. Economics Bulletin, 6(31), 1-13.

Majid, M. S. A. (2008). Does Financial Development Matter for Economic Growth in Malaysia? An ARDL Bound Testing Approach. Journal of Economic Cooperation, 29(1), 61-82.

Marlissa, E. R. (2016). Effect of Deposit Interest Regional Development Bank, Deposit Interest Rate Government Bank, Inflation, GDP and Money Supply Against Exchange Rate US Dollar. Journal of Economics and Behavioral Studies, 8(1), 79-86.

Miciuła, I. (2014). The Concept of FTS Analysis in Forecasting Trends of Exchange Rate Changes. Economics and Sociology, 7(2), 172-182.

Miranti, R. (2010). Poverty in Indonesia 1984-2002: The Impact of Growth and Changes in Inequality. Bulletin of Indonesian Economic Studies, 46(1), 79-97.

Narayan, P. K. (2005). The Saving and Investment Nexus for China: Evidence from Cointegration Tests. Applied Economics, Taylor and Francis Journals, 19(2), 245-261.

Neely, C. J., Sarno, L. (2002). How Well do Monetary Fundamentals Forecast Exchange Rate? Federal Reserve Bank of St. Louis Review, September/October, 51-74.

Pahlavani, M., Wilson, E., Worthington, A. C. (2005). Trade-GDP Nexus in Iran: An Application of the Autoregressive Distributed Lag (ARDL) Model. American Journal of Applied Sciences, 2(7), 1158-1165.

Pesaran, H. M., Pesaran, B. (1997). Microfit 4.0, Oxford University Press, England.

Pesaran, M. H., Shin, Y., Smith, R. J. (2001). Bounds Testing Approaches to the Analysis of Level Relationships. Journal of Applied Econometrics, 16(3), 289-326.

Puah, C. H., Hiew, L C. (2010). Financial Liberalization, Weighted Monetary Aggregates and Money Demand in Indonesia. Labuan Bulletin of International Business \& Finance, 8, 76-93.

Sianturi, R. H., Tanjung, A. F., Leong, C. M., Puah, C. H., Brahmana, R. K. (2017). Financial Liberalization and Divisia Money Demand in Indonesia. Advanced Science Letters, 23(4), 3155-3158.

Serletis, A., Gogas, P. (2014). Divisia Monetary Aggregates, the Great Ratios, and Classical Money Demand Functions. Journal of Money, Credit and Banking, 46(1), 229-241.

Simwaka, K. (2004). Monetary Model of Exchange Rate: Empirical Evidence from Malawi. Available at SSRN: http//dx.doi.org/10.2139/ssrn.569332

Stern, J. (2003). The Rise and Fall of the Indonesian Economy. Kennedy School of Government, Harvard Faculty Research Working Paper Series No. RWP03-030.

Tang, M. M.-J., Puah, C. H., Affendy Arip, M., Dayang Affizah, A. M. (2015). Forecasting Performance of the P-star Model: The Case of Indonesia. Journal of International Business and Economics, 15(2), 7-12.

Taylor, M. P., Peel, D. A. (2000). Nonlinear Adjustment, Long-run Equilibrium and Exchange Rate Fundamentals. Journal of International Money and Finance, 19, 33-53.

Warjiyo, P. (2013). Indonesia: Stabilizing the Exchange Rate along Its Fundamental. BIS Paper No. 73.

Weliwita, A., Ekanayake, E. M. (1998). Demand for Money in Sri Lanka during the Post1977 Period: A Cointegration and Error Correction Analysis. Applied Economics, 30, 1219-1229. 